\title{
Effect of Arsenic and Selenium on Nickel in SOFC Anode Materials
}

\author{
Kazuhiro KumABE ${ }^{\dagger}$, Tomoki UchidA, Yusuke KikUchi, and Hiroshi Moritomi
}

(Received January 5, 2018)

\section{ヒ素およびセレンの SOFC アノード材中ニッケルに及ぼす影響}

隈部和弘 ${ }^{\dagger}$, 内田智毅, 菊地悠介, 守富 寛

The effect of arsenic and selenium in coal gasification gas on nickel in SOFC anode materials was investigated using a commercial thermodynamic equilibrium calculation software, batch reactor, and digital microscope. The thermodynamic equilibrium simulations of $0.5 \mathrm{CO}, 0.2 \mathrm{H}_{2}, 0.04 \mathrm{CO}_{2}, 0.26 \mathrm{~N}_{2}, 0.2 \mathrm{H}_{2} \mathrm{O}, 10 \mathrm{Ni}$, and arsenic and/or selenium were carried out to result in forming NiAs as solid-phase species under the conditions more than $10 \mathrm{ppm}$ arsenic, the equivalent amount of NiAs as solid-phase species and AsSe as gas-phase species under the conditions of 10-1000 ppm arsenic and selenium, and $\mathrm{Ni}_{7} \mathrm{Se}_{8}$ as solid-phase species under the conditions more than $1 \%$ selenium. The impedance of nickel wire with arsenic and selenium from 500 to $900{ }^{\circ} \mathrm{C}$ in the batch reactor was measured under simulated coal gasification gas $\left(\mathrm{H}_{2} / \mathrm{N}_{2}=30 / 70 \mathrm{vol} \%\right)$ by a digital multi-meter to result in increasing the impedance with $>0.05 \mathrm{~g}$ arsenic and $>0.05 \mathrm{~g}$ selenium due to nickel corrosion. The reaction of nickel plate with arsenic and/or selenium to $900{ }^{\circ} \mathrm{C}$ in the batch reactor and digital microscope was performed under simulated coal gasification gas $\left(\mathrm{CO} / \mathrm{CO}_{2} / \mathrm{N}_{2} / \mathrm{H}_{2}=50.0 / 4.00 / 26.0 / 20.0\right.$ vol\%) to result in the corrosion on the surface of nickel plate due to forming $\mathrm{Ni}_{5} \mathrm{As}_{2}$ and pumping nickel by arsenic.

石炭ガス化ガス中ヒ素拉よびセレンの SOFC アノード材中ニッケルへの影響を市販の熱力学平衡計算ソフトウェア, 回分 式反応器, デジタル顕微鏡を用いて検討した。 $0.5 \mathrm{CO}, \quad 0.2 \mathrm{H}_{2}, \quad 0.04 \mathrm{CO}_{2}, \quad 0.26 \mathrm{~N}_{2}, \quad 0.2 \mathrm{H}_{2} \mathrm{O}, \quad 10 \mathrm{Ni}$, ヒ素, セレンの熱力 学平衡計算は, $10 \mathrm{ppm}$ 以上のヒ素存在下では固相の NiAs が生成, 10-1000 ppm のヒ素およびセレン存在下では固相の $\mathrm{NiAs}$ と気相の AsSe が生成, $1 \%$ 以上のセレン存在下では固相の $\mathrm{Ni}_{7} \mathrm{Se}_{8}$ が生成する結果を示した。回分式反応器中模擬 石炭ガス化ガス $\left(\mathrm{H}_{2} / \mathrm{N}_{2}=30 / 70 \mathrm{vol} \%\right)$ 雲囲気で500-900ㄷ に拈けるヒ素およびセレン存在下でのニッケル線のインピーダ ンスをデジタルマルチメーターを用いて測定したところ, $0.05 \mathrm{~g}$ 以上のヒ素およびセレン存在下でニッケル腐食によりインピー ダンスが増加した。回分式反応器およびデジタル顕微鏡においてヒ素およびセレンとニッケル板を模擬石炭ガス化ガス (CO/ $\left.\mathrm{CO}_{2} / \mathrm{N}_{2} / \mathrm{H}_{2}=50.0 / 4.00 / 26.0 / 20.0 \mathrm{vol} \%\right)$ 中 $900^{\circ} \mathrm{C}$ までで反応させたところ, $\mathrm{Ni}_{5} \mathrm{As}_{2}$ の生成拉よびヒ素によるニッケルのポ ンピング現象により, ニッケル板表面上が腐食した。

\section{Key Words}

SOFC, Anode, Nickel, Coal gasification, Arsenic, Selenium

\section{1. 緒 言}

これまでに天然ガスを利用した家庭用 SOFC の研究開発 が進められ，2011 年にはSOFCエネファームの市販が開始 されている。燃料多様化の観点から, 将来的には石炭ガス 化ガスを燃料とした電気事業用の SOFC 発電 (石炭ガス化燃 料電池複合発電, IGFC) が期待されている。SOFCは高温 (600-1000) で作動し, スタック内部での燃料改質が可能

Division of Environmental and Renewable Energy Systems, Graduate School of Engineering, Gifu University

1-1, Yanagido, Gifu-shi, Gifu 501-1193, Japan

† Corresponding author: k_kumabe@gifu-u.ac.jp
なため，原理的には石炭ガス化ガスを直接利用できる。しか し, 石炭ガス化ガスに微量に含まれる種々な不純物と SOFC アノード材間の化学反応により, アノードの電気化学反応に 関する性能の低下を招く可能性がある1)。

石炭ガス化ガスに微量に含まれる重金属不純物および有 害元素としては, ヒ素, ホウ素, カドミウム, 鉛, 水銀, モリブデン, セレン等がある2。著者らは, 市販の熱力学

岐阜大学大学院工学研究科環境エネルギーシステム専攻 × 501-1193 岐阜県岐皁市柳戸 1-1 
平衡計算ソフト (FactSage 6.0, ThermFact Inc. and GTTTechnologies）を用いてこれらの重金属不純物と有害元素, 公表されている石炭ガス化(EAGLE) ガス組成 ${ }^{3)}$, SOFC アノー ド材成分 $\left(\mathrm{ZrO}_{2}\right.$ および $\left.\mathrm{NiO}\right)$ の熱力学平衡状態での化学形 態を調べたところ, $900^{\circ} \mathrm{C}$ 以下で重金属不純物と SOFC アノー ド材成分と化合するのはヒ素，セレン， $\mathrm{NiO}$ であることがわ かった ${ }^{4)}$ 。本調査ではSOFCアノード材中ニッケル成分を原 料の $\mathrm{NiO}$ と仮定していたが，SOFC 作動時におけるアノード 材中ニッケル成分は $\mathrm{NiO}$ が還元されたニッケル金属単体 $(\mathrm{Ni})$ である。しかし, 本調査は「熱力学平衡状態」での化学形 態調査であるため, アノード材中ニッケル成分として $\mathrm{NiO}$ あ るいは $\mathrm{Ni}$ の゙ちらを仮定しても，調査結果は等しい。その ため, 本研究では SOFC 作動時におけるアノード材中ニッケ ル成分 $(\mathrm{Ni})$ と化合する重金属不純物としてヒ素拉よびセレ ンに着目する。

これまでにヒ素, セレン，石炭ガス化ガス，SOFCアノー ド材成分の反応・腐食および発電特性に関する研究が行わ れている。Trembly et al. はガス精製後の石炭ガス化ガス中 アンチモン, ヒ素, カドミウム, 鉛, 水銀, リン, 亜鉛, セ レンの SOFC アノード材中ニッケルとの反応を熱力学平衡計 算によって理論的に調査しており, アンチモン, ヒ素, リン がニッケルと反応する可能性があることを示唆している5)。 Martinez et al. もガス精製後の石炭ガス化ガス中硫黄, カド ミウム, アンチモン, 塩素, リン, 七素, 水銀の SOFC アノー ド材中ニッケルとの反応を熱力学平衡計算によって理論的 に調査しており，アンチモン，リン，ヒ素がニッケルと反応 する可能性があることを示唆している ${ }^{6)}$ 。一方，実験的調査

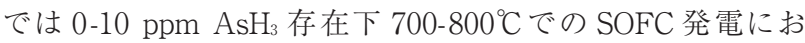
ける出力密度, 出力割合, インピーダンス等が調査されてお り，発電時間経過とともに $\mathrm{AsH}_{3}$ 濃度と温度が高いほど出 力密度と出力割合が低下したこと7) 9)，および発電時間経 過とともにZ'-(-Z”) 軸インピーダンスプロットが正方向に増 加したこと ${ }^{10)}$ が報告されている。セレンに関しては Gerdes et al. が 0.5 抢よび $5 \mathrm{ppm} \mathrm{H}_{2} \mathrm{Se}$ 存在下 $800{ }^{\circ} \mathrm{C} て ゙ の ~ S O F C$ 発 電に抒ける出力密度を調査しており, 発電時間経過とともに $\mathrm{H}_{2} \mathrm{Se}$ 濃度が高いほど出力密度が低下したことを報告してい る ${ }^{11}$ 。 Hackett et al. はヒ素濃度は検出限界以下，七レン濃度 は 0.8-0.9 ppm である実際の石炭ガス化ガス(他の微量成分: 2.7-3.5 ppm クロム, 1-3.2 ppm 鉛, 2.1-9.4 ppm 水銀, 2.1$2.3 \mathrm{ppm}$ ニッケル, $2 \mathrm{ppm}$ 未満 硫黄, 42.6-179.5 ppm スズ, 53.4-94.6 ppm 亜鉛) を用いた SOFC 発電特性を調査してお り， 0-375 $\mathrm{mA} / \mathrm{cm}^{2}$ の電流密度で 9-19\%/1000 h 性能が劣化 したことを報告している12)。しかし，ヒ素およびセレンのみ
が存在する石炭ガス化ガスの SOFC アノード材中ニッケルへ の影響を理論的および実験的に調査した研究は，著者の知 るところ見当たらない。

本研究では, 石炭ガス化ガス中ヒ素㧍よびセレンの SOFC アノード材中ニッケルへの影響を市販の熱力学平衡計算ソフ トウェア, 回分式反応器, デジタル顕微鏡を用いて検討した。

\section{2. 熱力学平衡計算}

熱力学平衡計算は, 溶融相のデータベース (FACT-FeS and FACT-SlagA）を有する市販の熱力学平衡計算ソフト (FactSage 6.0, ThermFact Inc. and GTT-Technologies) を用 いて $\mathrm{CO}, \mathrm{H}_{2}, \mathrm{CO}_{2}, \mathrm{~N}_{2}, \mathrm{H}_{2} \mathrm{O}, \mathrm{Ni}$, ヒ素, セレンに関して行っ た。初期入力条件を Table 1 に示す。 $\mathrm{CO}, \mathrm{H}_{2}, \mathrm{CO}_{2}, \mathrm{~N}_{2}$, $\mathrm{H}_{2} \mathrm{O}$ は公表されている石炭ガス化 (EAGLE) ガス組成を参 考に設定した ${ }^{3)}$ 。 Ni は過剩量の $10 \mathrm{~mol}$ とした。ヒ素は $1 \times$ $10^{-7}-1 \times 10^{-1} \mathrm{~mol}$ で設定し，これは石炭ガス化ガス中では $0.1 \mathrm{ppm}-10 \%$ の濃度に相当する。セレンは 0-1 × $10^{-1} \mathrm{~mol}$ で設定し， 0 ppm-10\%の濃度に相当する。圧力は $1 \mathrm{atm,}$ 温度は $900^{\circ} \mathrm{C}$ とした。すおわち, 本熱力学平衡計算では $1 \mathrm{~atm}, 900^{\circ} \mathrm{C}$ の石炭ガス化ガス中ヒ素濃度が $0.1 \mathrm{ppm}-10 \%$ およびヒ素・セレン等量混合濃度が 0.2 ppm-20\%において, それぞれ固相の NiAs が生成する濃度範囲およびヒ素・セレ ンに関する化合物が生成する濃度範囲を検討した。

\section{3. 実 験}

\section{1 回分式反応器中でのニッケル線インピーダンス測定}

回分式反応器中でヒ素拉よびセレン存在下でのニッケル線 のインピーダンス測定を行った。実験装置図を Fig. 1に示す。 内径 $30 \mathrm{~mm} \times$ 長さ $600 \mathrm{~mm}$ のアルミナ管内に直径 $0.3 \mathrm{~mm}$ ×長さ $700 \mathrm{~mm}$ のニッケル線拈よび試薬ヒ素 (Nacalai Tesque, Inc.) ・ セレン (Kanto Chemical Co., Inc.) 混合物（そ れぞれ $0,0.01 ， 0.05 ， 0.1 \mathrm{~g}$ ずつ）が入った縦 $74 \mathrm{~mm} \times$ 横 $11 \mathrm{~mm} \times$ 高さ $10 \mathrm{~mm}$ の燃焼ボートを置いた。模擬石炭ガス 化ガス $\left(\mathrm{H}_{2} / \mathrm{N}_{2}=29 / 71 \mathrm{vol} \%\right)$ を流通させて空気パージを 確認後, シリコン栓でアルミナ管両端を密閉した。その後, 長さ $250 \mathrm{~mm}$ の電気炉でアルミナ管を加熱し, $20^{\circ} \mathrm{C}$ およ゙ 500-900ㄷに扮ける昇温・冷却過程（それぞれ 2 h）でのイ ンピーダンス変化をデジタルマルチメーター (Digital Hitester 3239, Hioki E. E. Co.）を用いて四端子法で測定した。

室温まで冷却後ニッケル線を回収し, 燃焼ボート付近 のニッケル線を長さ $30 \mathrm{~mm}$ で切断し, 市販のエポキシ樹 脂（jER 828, Mitsubishi Chemical Corporation）で固化させ て研磨し, 卓上顕微鏡 (Miniscope TM3000, Hitachi High-

Table 1 Input values in the thermodynamic equilibrium simulation of the reactions of arsenic and/or selenium with nickel in coal gasification gas

\begin{tabular}{crrrrr}
\hline Elements & {$[\mathrm{mol}]$} & Elements & \multicolumn{1}{c}{$[\mathrm{mol}]$} & \multicolumn{1}{c}{ Elements } & \multicolumn{1}{c}{$[\mathrm{mol}]$} \\
\hline $\mathrm{CO}$ & 0.5 & $\mathrm{~N}_{2}$ & 0.26 & As & $1 \times 10^{-7}-1 \times 10^{-1}$ \\
\hline $\mathrm{H}_{2}$ & 0.2 & $\mathrm{H}_{2} \mathrm{O}$ & 0.2 & $\mathrm{Se}$ & $0-1 \times 10^{-1}$ \\
\hline $\mathrm{CO}_{2}$ & 0.04 & $\mathrm{Ni}$ & 10 & & \\
\hline
\end{tabular}




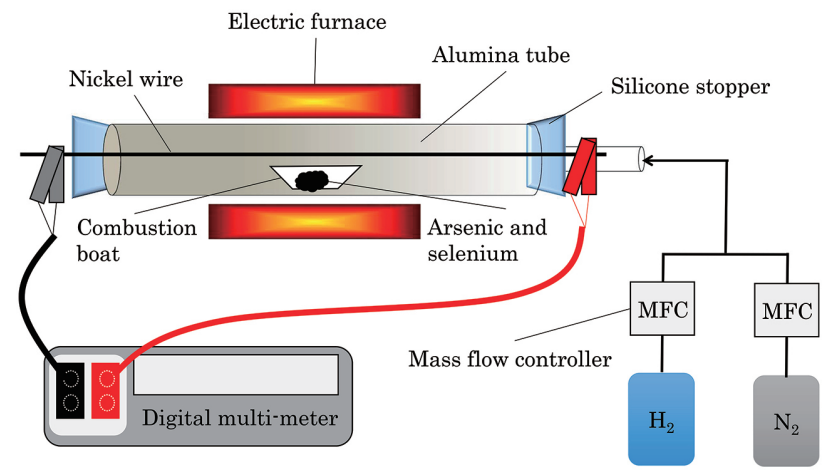

Fig. 1 Schematic diagram of experimental setup for impedance measurement of nickel wire with arsenic and selenium from 500 to $900^{\circ} \mathrm{C}$ in batch reactor

Technologies Corporation) およびエネルギー分散型 X 線 分析装置 (Quantax70, Bruker AXS K.K.) が一体となった SEM-EDX を用いてニッケル線断面を観察・元素分析した。

\section{2 回分式反応器中でのヒ素およびセレンによるニッケル 板加速腐食試験}

回分式反応器中でヒ素およびセレンによるニッケル板加速 腐食試験を行った。実験装置図をFig. 2 に示す。内径 45 $\mathrm{mm} \times$ 長さ $235 \mathrm{~mm}$ の石英管内に縦 $150 \mathrm{~mm} \times$ 横 $150 \mathrm{~mm}$ ×厚さ $1 \mathrm{~mm}$ の $1.96 \mathrm{~g}$ のニッケル板および $0.1 \mathrm{~g}$ の試薬ヒ素 (Nacalai Tesque, Inc.) またはヒ素・セレン (Kanto Chemical Co., Inc.) 混合物（各 $0.1 \mathrm{~g}$ ）を入れた縦 $74 \mathrm{~mm} \times$ 横 $11 \mathrm{~mm}$ ×高さ $10 \mathrm{~mm}$ の燃焼ボートを置いた。模擬 EAGLEガス $(\mathrm{CO} /$ $\mathrm{H}_{2} / \mathrm{CO}_{2} / \mathrm{N}_{2}=50 / 20 / 4 / 26 \mathrm{vol} \%$ ) 3) を直径 $45 \mathrm{~mm} \times$ 長さ $135 \mathrm{~mm}$ の石英ピストン中直径 $10 \mathrm{~mm}$ のガス注入口より流通 させて空気パージを確認後, 石英ピストンおよびシリカペー パーで石英管を密閉し，ニードルバルブを閉じた。その後, 電気炉で石英管を 1-2 h で 800-900ㄷ に加熱し, 4 h 保持した。 この場合，模擬 EAGLE ガス中ヒ素またはヒ素・セレン混合 物濃度は約 $10 \%$ に相当し, 既往の当該研究 7) 11) でのヒ素. セレン濃度 (0-10 ppm) および実際の石炭ガス化ガス中ヒ 素・セレン濃度 (0-1 ppm) 12) と大きく異なる。しかし, 本研 究に先立って各 $10 \mathrm{ppm}$ のヒ素・セレン混合物を用いて $28 \mathrm{~h}$, $50 \mathrm{ppm}$ のヒ素を用いて $180 \mathrm{~h}$ のニッケル板腐食試験を行っ

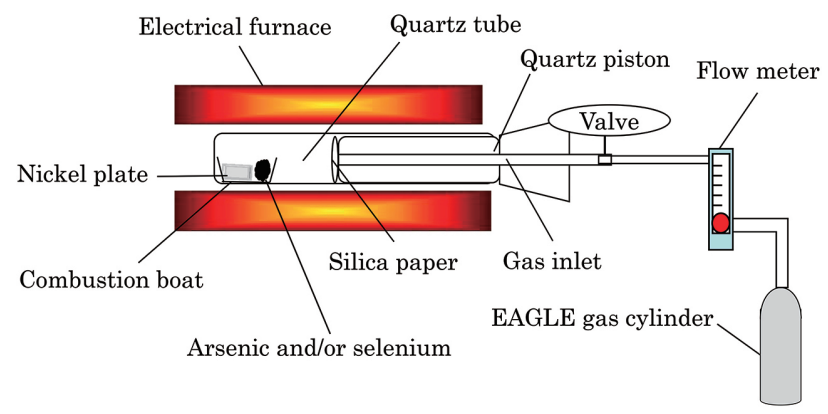

Fig. 2 Schematic diagram of experimental setup for accelerated corrosion test of nickel plate with arsenic and/or selenium at $800-900^{\circ} \mathrm{C}$ in batch reactor
たところ，ヒ素およびセレンのニッケルへの影響は見られな

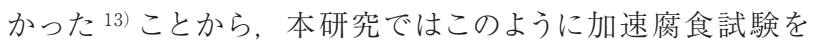
行った。

室温まで冷却後ニッケル板を回収し， 3.1 節で述べた SEM-EDXを用いてニッケル板表面および断面を観察・ 元素分析した。さらに, ニッケル板表面構造のX線回折 (XRD) 分析を市販の装置 (LabX XRD-6100, Shimadzu Corporation）を用いて行った。

\section{3 光学顕微鏡を用いたヒ素およびセレンによるニッケル 板表面腐食観察}

ヒ素およびセレンによるニッケル板加速腐食を in-situ 観察 するために, Fig. 3 に示す石英製加熱冷却ステージ (IR-TP-S, Yonekura Manufacturing Co.,Ltd.) 付きデジタル顕微鏡 (VHX1000, Keyence Corporation）を用いた。縦 $80 \mathrm{~mm} \times$ 横 26 $\mathrm{mm} \times$ 高さ $115 \mathrm{~mm}$ の加熱冷却ステージ内に設置された外 径 $9 \mathrm{~mm} \times$ 内径 $6 \mathrm{~mm} \times$ 長さ $95 \mathrm{~mm}$ の石英管先端に接合さ れている縦 $20 \mathrm{~mm} \times$ 横 $20 \mathrm{~mm} \times$ 厚さ $1 \mathrm{~mm}$ の試料ホルダー 上に縦 $150 \mathrm{~mm} \times$ 横 $150 \mathrm{~mm} \times$ 厚さ $1 \mathrm{~mm}$ の $1.96 \mathrm{~g}$ のニッ ケル板を置き, $0.1 \mathrm{~g}$ の試薬ヒ素 (Nacalai Tesque, Inc.) およ び $0.1 \mathrm{~g}$ の試薬セレン (Kanto Chemical Co., Inc.) 混合物を加 熱冷却ステージ内のガス注入口直下に置いた。模擬 EAGLE ガス $\left(\mathrm{CO} / \mathrm{H}_{2} / \mathrm{CO}_{2} / \mathrm{N}_{2}=50 / 20 / 4 / 26 \mathrm{vol} \%\right)$ 3) をガス注入口 より流通させて空気パージを確認後, フローメーターで流量 を $25 \mathrm{~mL} / \mathrm{min}$ に調整した模擬 EAGLE ガス流通下において, 熱電対が接続された試料ホルダーを Fig. 4 に示すように $1 \mathrm{~h}$ で $25^{\circ} \mathrm{C}$ から $900^{\circ} \mathrm{C}$ に加熱して, 数時間保持後, $1 \mathrm{~h}$ で $25^{\circ} \mathrm{C}$ に冷却する操作を 15 回繰り返した。 $900^{\circ} \mathrm{C}$ の保持時間は 4 , $5,5,4,6,4,5,4,5,5,4,5,5,5,3 \mathrm{~h}$ の計 $69 \mathrm{~h}$

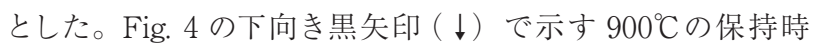
間が計 $0 ， 14 ， 24 ， 33 \mathrm{~h}$ において，それぞれ $0.1 \mathrm{~g}$ の試薬 ヒ素および試薬セレン混合物を加熱冷却ステージ内のガス

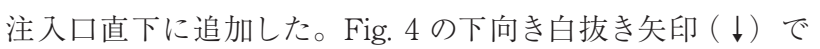
示す $900^{\circ} \mathrm{C}$ の保持時間が計 $37,42,47,51,56,61,66$,

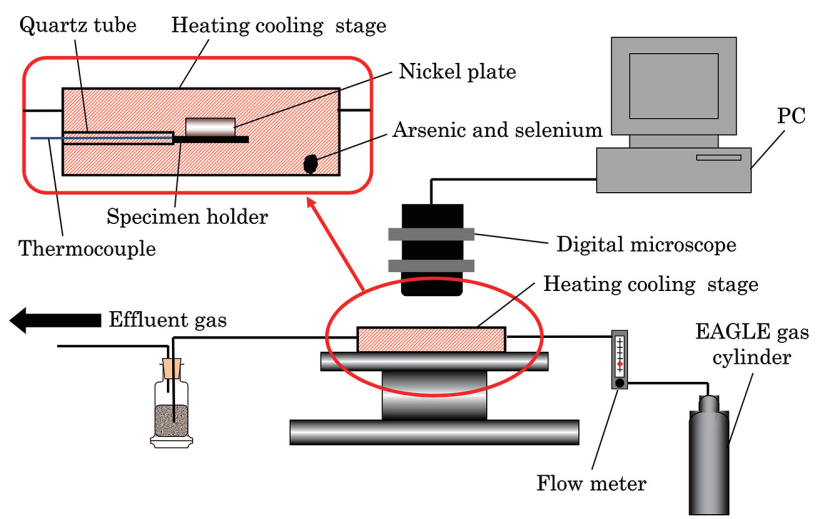

Fig. 3 Schematic diagram of digital microscope for accelerated corrosion observation of nickel plate with arsenic and selenium at $900{ }^{\circ} \mathrm{C}$ in heating-cooling stage 


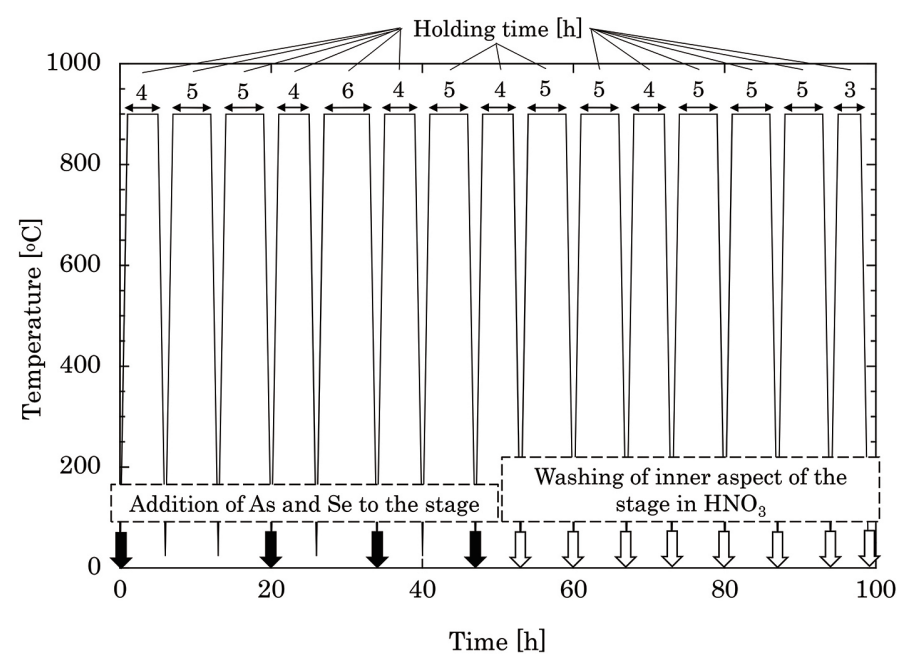

Fig. 4 Change in temperature in heating-cooling stage with time for accelerated corrosion observation of nickel plate with arsenic and selenium

$69 \mathrm{~h}$ において, $13 \mathrm{~mol} / \mathrm{L}$ 濃硝酸（Nacalai Tesque, Inc.) を 16 倍に希釈した希硝酸を用いて, 石英製加熱冷却ステージ 内部に付着したヒ素およびセレンを洗浄した。15 回の加熱前 のニッケル板の重量を測定するとともに，デジタル顕微鏡を 用いて 15 回の加熱前後のニッケル板表面をin-situ 観察した。

15 回の加熱・保持・冷却終了後, 3.1 節で述べた SEMEDX を用いてニッケル板表面を観察・元素分析した。

\section{4. 結果および考察}

\section{1 熱力学平衡計算}

$1 \mathrm{~atm}, 900^{\circ} \mathrm{C}$ の EAGLE ガス中ヒ素物質量が $1 \times 10^{-7}-1 \times$ $10^{-1} \mathrm{~mol}$ （濃度 $0.1 \mathrm{ppm}-10 \%$ ） およびヒ素・セレン等量混合 物質量が $2 \times 10^{-7}-2 \times 10^{-1} \mathrm{~mol}$ （濃度 $0.2 \mathrm{ppm}-20 \%$ ）である 熱力学平衡状態における固相 NiAs が生成する濃度範囲お よびヒ素・セレンに関する化合物が生成する濃度範囲の計算 結果をそれぞれ Figs. 5, 6 に示す。Fig. 5 において，破線は $\mathrm{NiAs}$ の理論最大生成物質量, 実線は固相 $\mathrm{NiAs} の$ 生成物 質量を示している。ヒ素濃度が $10 \mathrm{ppm}$ 以上である場合に固 相 NiAs が生成することがわかる。ここで，本研究で用いた 市販の熱力学平衡計算ソフトには $\mathrm{Ni}_{5} \mathrm{As}_{8}$ 等の他のニッケル 七素化合物データは含まれていない。この計算結果は，石 炭ガス化ガス中にヒ素が存在する場合, SOFCアノード材中 ニッケルへ影響を与える可能性を示唆している。

Fig. 6 において，プロットの無い破線はヒ素 and/or セレ ン含有化合物の理論最大生成物質量, 四角 $(\square)$ のプロッ トは固相 $\mathrm{NiAs}$, 丸 $(\bigcirc)$ のプロットは固相 $\mathrm{Ni}_{7} \mathrm{Se}_{8}$, 三角 $(\triangle)$ のプロットは気相 AsSe を示している。ヒ素およびセレンが 等量で存在する場合, 固相 NiAs に加えて気相 AsSe が生成 することがわかる。ヒ素・セレン等量混合物濃度が $2 \%$ 以上 の場合に固相 $\mathrm{Ni}_{7} \mathrm{Se}_{8}$ が生成するが，実際の石炭ガス化ガス においてはヒ素およびセレンがこのような高濃度で存在する ことは考えに(い7) 12)。この計算結果は，石炭ガス化ガス 中にヒ素抢よびセレンが存在する場合, SOFCアノード材中

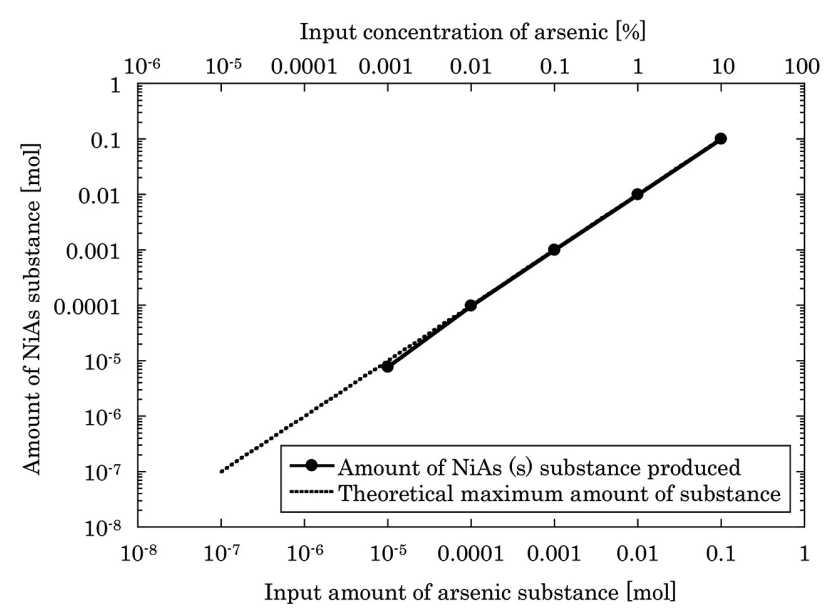

Fig. 5 Change in amount of $\mathrm{NiAs}$ substance produced with input amount of arsenic substance under thermodynamic equilibrium state

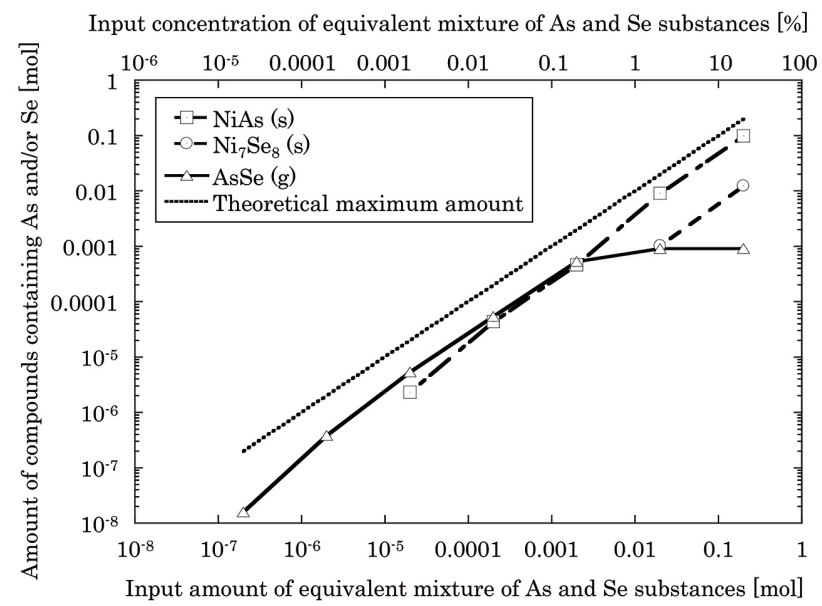

Fig. 6 Change in amount of compounds containing As and/or Se produced with input amount of equivalent mixture of As and Se substances under thermodynamic equilibrium state 
ニッケルヘ影響を与えるが，気相 AsSe の生成によりその影 響の低減の可能性を示唆している。

以上の計算結果を踏まえて，3章の実験を行った。

\section{2 回分式反応器中でのニッケル線インピーダンス測定}

$\mathrm{H}_{2} / \mathrm{N}_{2}=29 / 71 \mathrm{vol} \%$ のガス中ヒ素・セレン混合物存在下 での $20^{\circ} \mathrm{C}$ および 500-900ㄷ に㧍ける昇温・冷却過程でのニッ ケル線のインピーダンス変化を Fig. 7 に示す。ここで, プロッ トの無い直線は理論值を示し, 以下の $(1) \sim(3)$ 式を用い て $R_{t{ }^{\circ} \mathrm{C}}(@ 0.25 \mathrm{~m})$ として算出した ${ }^{14)}$ :

$$
\begin{aligned}
\left.R_{20}{ }^{\circ} \mathrm{C} @ 0.7 \mathrm{~m}\right)= & \rho \times \frac{L}{S}=7.24 \times 10^{-8}[\Omega \cdot \mathrm{m}] \\
& \times \frac{0.7[\mathrm{~m}]}{\left(0.3 \times 10^{-3} \div 2\right)^{2} \times 3.14\left[\mathrm{~m}^{2}\right]}=0.717[\Omega] \\
R_{t}{ }^{\circ \mathrm{C}}(@ 0.7 \mathrm{~m})= & \left.\mathrm{R}_{20^{\circ} \mathrm{C}} @ 0.7 \mathrm{~m}\right) \times\left\{1+\alpha_{20}{ }^{\circ} \mathrm{C}(t-20)\right\}[\Omega](2) \\
R_{t}{ }^{\circ} \mathrm{C}(@ 0.25 \mathrm{~m})= & \left.R_{t}{ }^{\circ} \mathrm{C} @ 0.7 \mathrm{~m}\right)+a_{0.7 \mathrm{~m}} \times \frac{0.25[\mathrm{~m}]}{0.70[\mathrm{~m}]} \times(t-20)[\Omega]
\end{aligned}
$$

$R_{20^{\circ} \mathrm{C}}(0.7 \mathrm{~m})$ は $20^{\circ} \mathrm{C}$, 直径 $0.3 \mathrm{~mm} \times$ 長さ (L) $700 \mathrm{~mm}$ のニッケル線のインピーダンス計算值 $(=0.717 \Omega), \rho$ は $20^{\circ} \mathrm{C}$ におけるニッケルの電気抵抗率, S はニッケル線の断面積で ある。 $R_{t}{ }^{\circ} \mathrm{C}(@ 0.7 \mathrm{~m})$ は $t^{\circ} \mathrm{C}$, 直径 $0.3 \mathrm{~mm} \times L 700 \mathrm{~mm} の$ ニッケル線のインピーダンス計算值 $(\Omega), \alpha_{20}{ }^{\circ} \mathrm{C}$ は $20^{\circ} \mathrm{C}$ におけ るニッケルの抵抗温度係数 $\left(=6.7 \times 10^{-3}{ }^{\circ} \mathrm{C}^{-1}\right)$ である。 $R_{t}{ }^{\circ} \mathrm{C}$ (@0.25 m) は $t^{\circ} \mathrm{C}$, 直径 $0.3 \mathrm{~mm} \times L 250 \mathrm{~mm}$ のニッケル 線のインピーダンス計算值 $(\Omega), a_{0.7 \mathrm{~m}}$ は $0.7 \mathrm{~m}$ におけるインピー ダンス計算值の傾き $\left(=4.8 \times 10^{-3} \Omega /{ }^{\circ} \mathrm{C}\right)$ である。最終的 に $R_{t}{ }^{\circ} \mathrm{C}(@ 0.25 \mathrm{~m})$ として理論值を算出したのは, 3.1 節で 述べたように電気炉(加熱部)の長さが $250 \mathrm{~mm}$ であるからで, (3) 式のように $0.25 \mathrm{~m}$ におけるインピーダンス計算值の傾き が $a_{0.7 \mathrm{~m}}$ に比例するのは (1) 式のようにインピーダンス計算值 は $L$ に比例するからである。

Fig. 7 において，丸（○・○）のプロットおよび実線・破
線は各 $0 \mathrm{~g}$ の試薬ヒ素・セレン混合物存在下での昇温・冷 却過程, 四角 $(\boldsymbol{\square} \cdot \square)$ のプロットおよび実線・破線は各 0.01 $\mathrm{g}$ の試薬ヒ素・セレン混合物存在下での昇温・冷却過程, ひ し形 $(\diamond ・ \diamond)$ のプロットおよび実線・破線は各 $0.05 \mathrm{~g}$ の試 薬ヒ素·セレン混合物存在下での昇温·冷却過程, 三角形

$\triangle$ ）のプロットおよび実線・破線は各 $0.1 \mathrm{~g}$ の試薬七素・セ レン混合物存在下での昇温・冷却過程におけるニッケル線の インピーダンス変化の実測值を示している。理論值よりも実 測值のニッケル線インピーダンスが高くなったのは, デジタ ルマルチメーターに接続している測定ケーブルの抵抗および 端子における接触抵抗の影響が大きいと考えられる ${ }^{14)}$ 。各 0 および $0.01 \mathrm{~g}$ の試薬ヒ素・セレン混合物存在下でのニッケ ル線のインピーダンス変化は昇温・冷却過程の間で差は小さ かったが, 各 0.05 および $0.1 \mathrm{~g}$ の試薬ヒ素・セレン混合物 存在下では冷却過程のインピーダンスは昇温過程よりも明ら かに増加した。これは，前述の（1）式のようにインピーダン スはニッケル線の断面積に反比例することから，七素・セレ ン混合物によるニッケル線の腐食により断面積が減少し，イ ンピーダンスを増加させたことが考えられる。

ヒ素・セレン混合物によるニッケル線の腐食を確認するた めに，SEM-EDXを用いて回収したニッケル線断面を観察・ 元素分析した。Fig. 8(a) - (e) にそれぞれ実験前, 各 0,0.01, $0.05,0.1 \mathrm{~g}$ の試薬ヒ素・セレン混合物存在下実験後のニッ ケル線断面の 300 倍 SEM 画像を示す。実験後のニッケル線 断面は外殼層が破壊され，断面積が減少している。特に， 各 0.05 および $0.1 \mathrm{~g}$ の試薬ヒ素・ セレン混合物存在下では 断面積の減少が顕著であり, 外殼層内面も破壊されている。 Fig. 9 (a) - (e)にそれぞれ実験前, 各 $0 ， 0.01 ， 0.05,0.1$ $\mathrm{g}$ の試薬ヒ素・セレン混合物存在下実験後のニッケル線断面 外殼部分の 1,000 倍 SEM-EDX 元素マッピング画像 (赤茶色 はニッケル, 淡青色は炭素, 緑色は酸素, オレンジ色はヒ素, 赤紫色はセレン）を示す。ニッケル線外側の炭素はニッケル 線回収・切断後の固化で用いた市販のエポキシ樹脂由来で

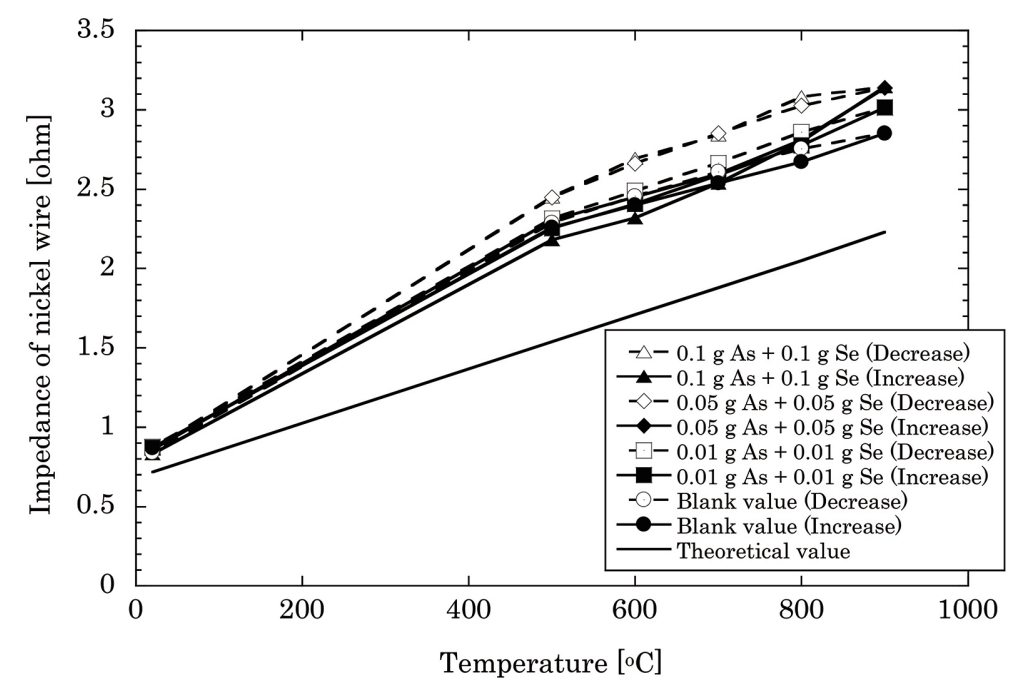

Fig. 7 Change in impedance of nickel wire with temperature for each input amount of equivalent mixture of As and Se substances 
(a) Before experiment

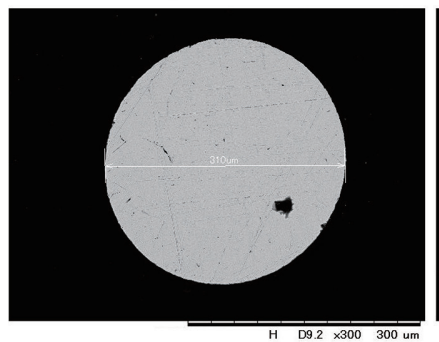

(d) 0.05 and $0.05 \mathrm{~g}$ of As and Se

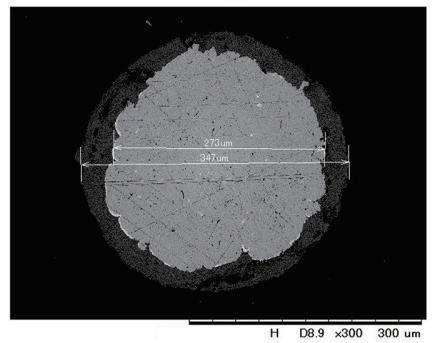

(b) 0 and $0 \mathrm{~g}$ of As and Se

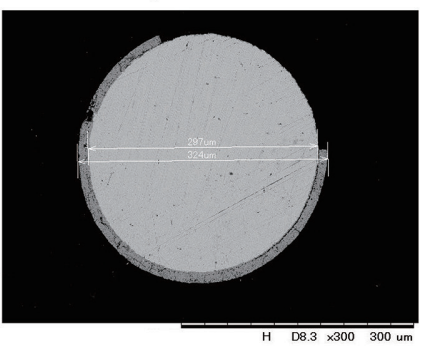

(e) 0.1 and $0.1 \mathrm{~g}$ of As and Se

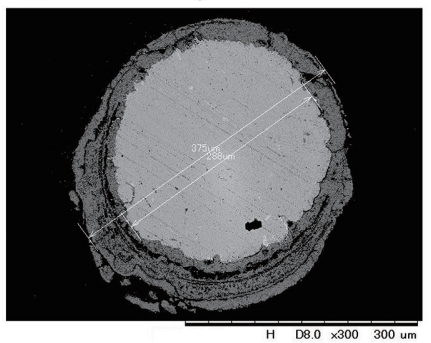

(c) 0.01 and $0.01 \mathrm{~g}$ of As and Se

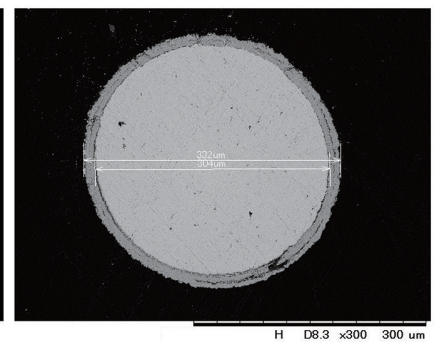

Fig. 8 SEM image, at magnification of 300 , of cross-section of nickel wires (a) before experiment and collected after experiments with (b) 0 and $0 \mathrm{~g}$, (c) 0.01 and $0.01 \mathrm{~g}$, (d) 0.05 and $0.05 \mathrm{~g}$, and (e) 0.1 and $0.1 \mathrm{~g}$ of arsenic and selenium, respectively

(a) Before experiment

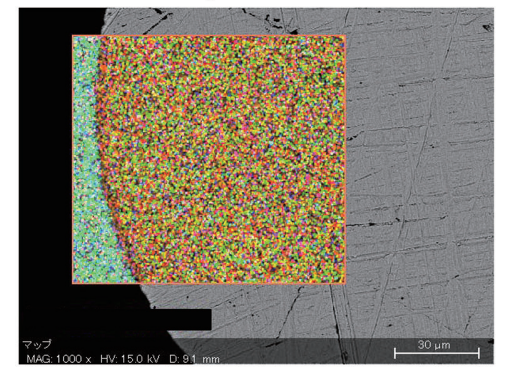

(b) 0 and $0 \mathrm{~g}$ of As and Se

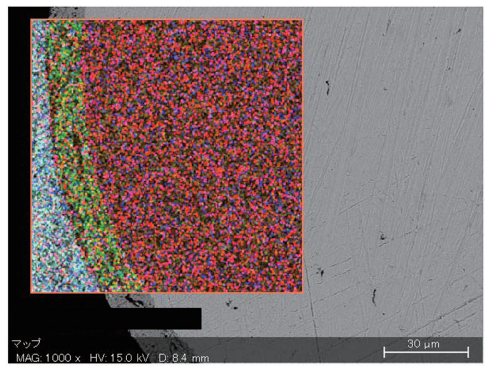

(c) 0.01 and $0.01 \mathrm{~g}$ of As and Se

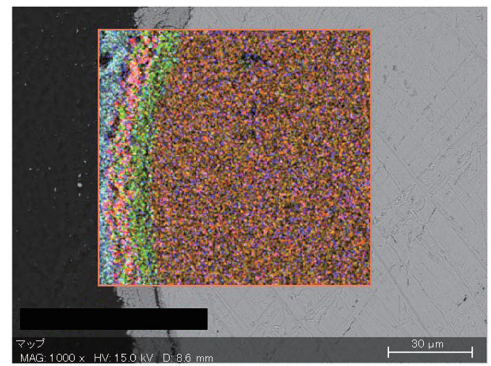

(d) 0.05 and $0.05 \mathrm{~g}$ of As and Se

(e) 0.1 and $0.1 \mathrm{~g}$ of As and Se
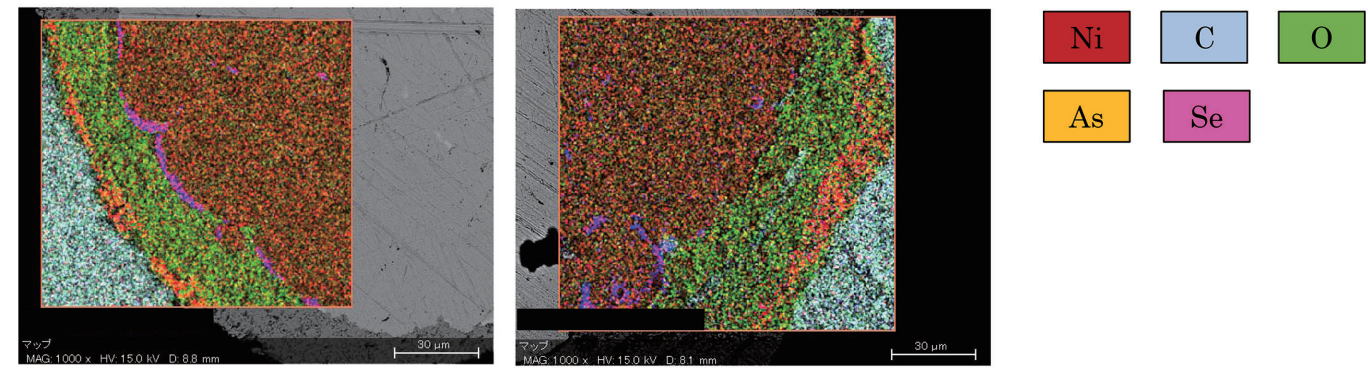

As

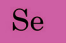

Fig. 9 SEM-EDX elemental mapping image, at magnification of 1,000, of cross-section shell region of nickel wires (a) before experiment and collected after experiments with (b) 0 and $0 \mathrm{~g}$, (c) 0.01 and $0.01 \mathrm{~g}$, (d) 0.05 and $0.05 \mathrm{~g}$, and (e) 0.1 and 0.1 $\mathrm{g}$ of arsenic and selenium, respectively

\section{ある。各 0.05 および $0.1 \mathrm{~g}$ の試薬ヒ素・セレン混合物存在 下ではニッケル線（赤茶色）と外殼層（緑色）の境界面にセ レンが, 外殼層とエポキシ樹脂の境界面にヒ素が存在した。 このように，七素は比較的ニッケル線表面で，セレンはニッ ケル線内部で多く確認された。}

4.3 回分式反応器中でのヒ素およびセレンによるニッケル 板加速腐食試験

Fig. 10 (a) - (d) にそれぞれ実験前, $0.1 \mathrm{~g}$ の試薬ヒ素存 在下 $800^{\circ} \mathrm{C}, 0.1 \mathrm{~g}$ の試薬ヒ素存在下 $900^{\circ} \mathrm{C}$, 各 $0.1 \mathrm{~g}$ の試 薬ヒ素・セレン混合物存在下 $900^{\circ} \mathrm{C} ゙$ の実験後に回収した ニッケル板表面画像を示す。実験後のニッケル板表面は腐食 されている。0.1 g の試薬七素存在下では $800^{\circ} \mathrm{C}$ と比較して 
(a) Before experiment

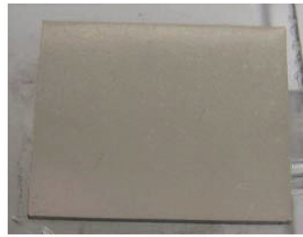

(c) $0.1 \mathrm{~g}$ of arsenic at $900{ }^{\circ} \mathrm{C}$

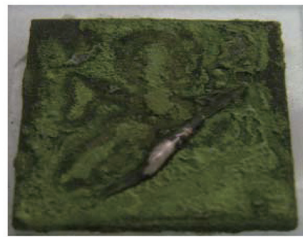

(b) $0.1 \mathrm{~g}$ of arsenic at $800^{\circ} \mathrm{C}$

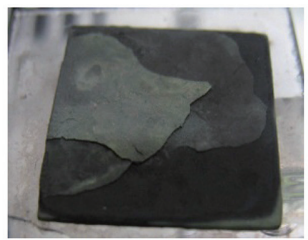

(d) $0.1 \mathrm{~g}$ and $0.1 \mathrm{~g}$ of arsenic and selenium at $900{ }^{\circ} \mathrm{C}$

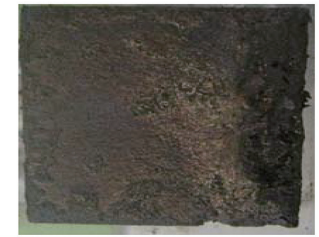

Fig. 10 Surface image of nickel plates (a) before experiment and collected after experiments with (b) $0.1 \mathrm{~g}$ of arsenic at $800^{\circ} \mathrm{C}$, (c) $0.1 \mathrm{~g}$ of arsenic at $900^{\circ} \mathrm{C}$, and (d) $0.1 \mathrm{~g}$ and $0.1 \mathrm{~g}$ of arsenic and selenium at $900^{\circ} \mathrm{C}$

$900^{\circ} \mathrm{C}$ の方が激しい腐食となっている。

$0.1 \mathrm{~g}$ の試薬ヒ素存在下 $800^{\circ} \mathrm{C}$ での実験後に回収したニッ ケル板を $800^{\circ} \mathrm{C}$ で $4 \mathrm{~h}$ 水素 $(25 \mathrm{~mL} / \mathrm{min})$ 還元した。Fig. 11 (a) - (c) にそれぞれ実験前と実験後のニッケル板表面 5,000 倍 SEM 画像拉よび実験後のニッケル板表面 5,000 倍 SEMEDX 元素マッピング画像（赤色はニッケル，緑色は七素）を 示す。実験前後のニッケル板表面 5,000 倍 SEM 画像を比較 すると, 実験後のニッケル板表面では溶融の跡・塊りが見ら れた。実験後のニッケル板表面 5,000 倍 SEM-EDX 元素マッ ピング画像では, 溶融の跡・塊りにはニッケルに加えてヒ素 が見られ，Fig. 11（b）の黄色の丸枠内でのニッケルおよびヒ 素の元素割合 [wt\%] はそれぞれ 78.3 および 16.1 であった。 Fig. 12 に実験後のニッケル板表面構造のXRD 分析結果を 示す。実験後のニッケル板表面にはニッケル $(+)$ に加えて,

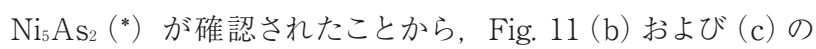
溶融の跡・塊りで見られたニッケルおよびヒ素は $\mathrm{Ni}_{5} \mathrm{As}_{2}$ であ ると考えられる。4.1節より熱力学平衡状態におけるヒ化ニッ ケル化合物形態は NiAsであったが, このように，実際のヒ 化ニッケル化合物形態は $\mathrm{Ni}_{5} \mathrm{As}_{2}$ であることがわかった。

各 $0.1 \mathrm{~g}$ の試薬ヒ素・セレン混合物存在下 $900^{\circ} \mathrm{C}$ での実験 後に回収したニッケル板を研磨・切断した。Fig. 13 に切断面 100 倍 SEM-EDX 元素マッピング画像 (オレンジ色枠内, 赤 色はニッケル, 緑色はヒ素, 青色はセレン) を示す。1の領 域側が燃焼ボード内に設置したニッケル板表面で，4の領域 側がニッケル板裏面（燃焼ボード内接地面）である。1〜4 の黄色の丸枠内の七素：セレン元素割合 [wt\%] はそれぞれ $7.0: 5.6,6.0: 19.6,0.0: 7.7,6.0: 2.4$ であった。このよう に，七素はニッケル板表面抢よび裏面で，セレンはニッケル

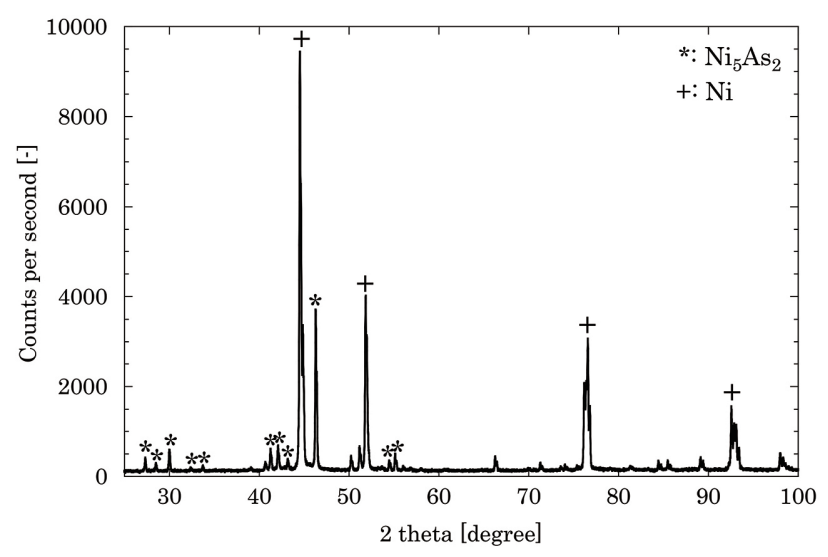

Fig. 12 XRD pattern of surface of nickel plate collected and reduced with hydrogen after experiment with $0.1 \mathrm{~g}$ of arsenic at $800^{\circ} \mathrm{C}$

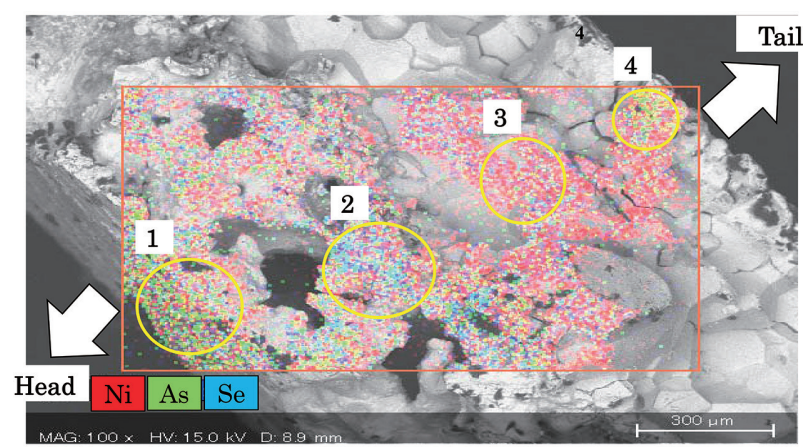

Fig. 13 SEM-EDX elemental mapping image, at magnification of 100 , of cross-section of nickel plate collected after experiments with 0.1 and $0.1 \mathrm{~g}$ of arsenic and selenium at $900^{\circ} \mathrm{C}$ (a) SEM image before experiment

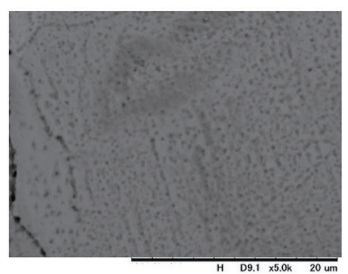

(b) SEM image after experiment

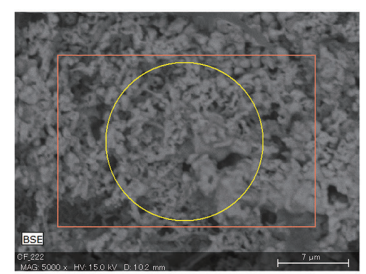

(c) SEM-EDX elemental mapping image after experiment

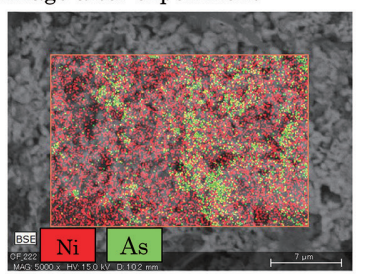

Fig. 11 SEM image, at magnification of 5,000, of surface of nickel plates (a) before experiment and (b) collected and reduced with hydrogen after experiment with $0.1 \mathrm{~g}$ of arsenic at $800^{\circ} \mathrm{C}$ and (c) SEM-EDX elemental mapping image, at magnification of 5,000 , of surface of nickel plates collected and reduced with hydrogen after experiment with $0.1 \mathrm{~g}$ of arsenic at $800^{\circ} \mathrm{C}$ 
板内部で多く確認され，この傾向は Fig. 9 (d) および (e)で も見られた。

したがって，ヒ素は主にニッケル線・板表面で捕捉されて $\mathrm{Ni}_{5} \mathrm{As}_{2}$ に転換するが， セレンは主にニッケル線・板内部で捕 捉されると考えられる。

\section{4 光学顕微鏡を用いたヒ素およびセレンによるニッケル 板表面腐食観察}

15 回の加熱前のニッケル板重量を測定した。ニッケル板 重量の時間変化を Fig. 14 に示す。ここで, Fig. 14 の上向き 黒矢印 $(\uparrow)$ で示す $900^{\circ} \mathrm{C}$ の保持時間が計 $0,14,24,33 \mathrm{~h}$ において，それぞれ $0.1 \mathrm{~g}$ のヒ素およびセレン混合物を加 熱冷却ステージに追加し，上向き白抜き矢印（†）で示す $900^{\circ} \mathrm{C}$ の保持時間が計 $37,42,47,51,56,61,66,69 \mathrm{~h}$ に招いて，希硝酸を用いて石英製加熱泠却ステージ内部に 付着したヒ素およびセレンを洗浄している。ヒ素抢よびセレン 混合物追加後のニッケル板重量は増加したが，希硝酸を用 いた加熱冷却ステージ内部洗浄後のニッケル板重量は減少 した。ヒ素の昇華点抢よびセレンの沸点はそれぞれ $615^{\circ} \mathrm{C}$ お よび $685^{\circ} \mathrm{C}$ であることから，この減少はニッケル板に物理吸 着したヒ素およびセレンの揮発に起因していると考えられる。

デジタル顕微鏡を用いて 15 回の加熱前後のニッケル板表 面をin-situ 観察した。ニッケル板表面画像の時間・温度変 化を Fig. 15 (1) - (39) に示す。ここで, Fig. 15 (1) - (11) は 100, (12) - (24) は200, (25) - (39) は1,000 倍の画像である。 Fig. 15 （13）- (16) および (37) - (39) の黄色の丸枠内で, ヒ 素 and/or セレンが内部のニッケルを周辺に析出させ，化合 物が生成し，再度ニッケル板に潜るポンピング現象が見られ た。特に,(37) - (39) では数分間でポンピング現象が生じた。

15 回の加熱・保持・冷却終了後, SEM-EDXを用いてニッ ケル板表面を観察・元素分析した。Fig. 16 (a) - (d)にそれ ぞれ SEM-EDX でヒ素拉よびセレンが多く観測されたニッケ ル板表面 1,000 倍 SEM 画像拈よび SEM-EDX 元素マッピン グ画像（赤色はニッケル, 緑色はヒ素, 青色はセレン）を示す。 Fig. 16（a）および (c)において, 比較的ヒ素が多く存在して

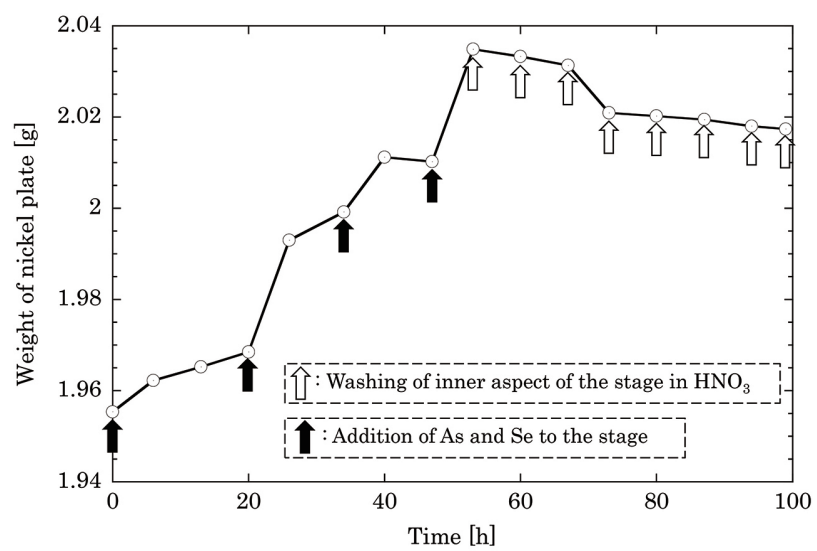

Fig. 14 Change in weight of nickel plate with time for accelerated corrosion observation of nickel plate with arsenic and selenium
いる領域では結晶のような構造が見られた。Fig. 12 より, こ れはヒ素がニッケルと反応して $\mathrm{Ni}_{5} \mathrm{As}_{2}$ を形成し，ポンピング 現象が生じたためと思われる。一方, Fig. 16（b）および (d) において，比較的セレンが多く存在している領域では結晶の ような構造が見られなかった。したがって, Fig. 11 (b) - (c), Fig. 15 （13）- (16)，（37）-（39）でも見られたポンピング現 象は, セレンではなくヒ素が内部のニッケルを周辺に析出さ せて $\mathrm{Ni}_{5} \mathrm{As}_{2}$ を形成したと考えられる。

以上より, 七素は主にニッケル表面で捕捉されて内部のニッ ケルを周辺にポンピングし， $\mathrm{Ni}_{5} \mathrm{As}_{2}$ を形成すると考えられる。 4.1 節の熱力学平衡計算結果は, 石炭ガス化ガス中にヒ素抒 よびセレンが存在する場合, SOFCアノード材中ニッケルへ 影響を与えるが, 気相 AsSe の生成によりその影響を低減で きる可能性を示している。しかし, 石炭ガス化ガス中にヒ素 が存在する場合, SOFC アノード材中ニッケル表面が腐食さ れることによって，SOFCアノード材中ニッケル内部が腐食さ れていない状態でも, SOFCアノードが突然死する可能性が あることを本研究は示唆している。したがって, 実際の石炭 ガス化ガスを用いて SOFC 発電を行う場合には，可能な限り ガス化ガス中ヒ素およびセレン濃度を低減することが望まれ る。

\section{5. 結 言}

本研究では石炭ガス化ガス中ヒ素拉よびセレンの SOFC アノード材中ニッケルへの影響を検討した。石炭ガス化 (EAGLE) ガス組成における熱力学平衡状態では, $10 \mathrm{ppm}$ 以上のヒ素存在下では固相の NiAs が生成, 10-1000 ppmの ヒ素およびセレン存在下では固相の NiAs と気相の AsSe が 生成, $1 \%$ 以上のセレン存在下では固相の $\mathrm{Ni}_{7} \mathrm{Se}_{8}$ が生成し た。模擬石炭ガス化ガス $\left(\mathrm{H}_{2} / \mathrm{N}_{2}=30 / 70 \mathrm{vol} \%\right)$ 䨌囲気では, 500- $900^{\circ} \mathrm{C}$ において $0.05 \mathrm{~g}$ 以上のヒ素およびセレンが存在す る場合, ニッケル腐食によりインピーダンスが増加した。ヒ 素およびセレンとニッケル板を模擬石炭ガス化 (EAGLE) ガ

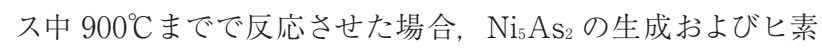
によるニッケルのポンピング現象により，ニッケル板表面上 が腐食した。

\section{文 献: References}

1) Kikuchi, R., J. Jpn. Inst. Energy, 91, 880-885 (2012) : 菊地 隆司, 日工六誌, 91, 880-885 (2012)

2) Yu, Y., Moritomi, H., Kambara, S., Yoshiie, R., Uemiya, S., J. Jpn. Inst. Energy, 84, 431-437 (2005) : 玉永壮，守富寛， 神原信志, 義家亮, 上宮成之, 日工ネ誌, 84, 431-437 (2005)

3) Sotooka, M., J. Jpn. Inst. Energy, 82, 836-840 (2003) : 外岡 正夫, 日工ネ誌, 84, 431-437 (2005)

4) Mizutani, S., Hayakawa Y., Moritomi, H., Kambara, S., Kumabe, K., Prep.47th Conference on Coal Science, No.21, Sep. 21-22, 2010, Gifu, Japan : 水谷晋, 早川幸男, 守富寛, 神原信志, 隈部和弘, 第 47 回石炭科学会議, No.21，2010.9.21-22，岐阜 


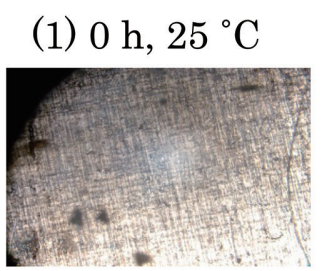

(6) $21 \mathrm{~h}, 900{ }^{\circ} \mathrm{C}$

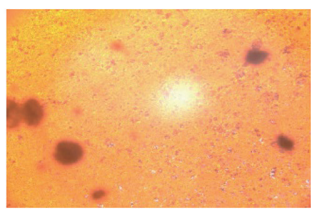

(11) $34 \mathrm{~h}, 25^{\circ} \mathrm{C}$

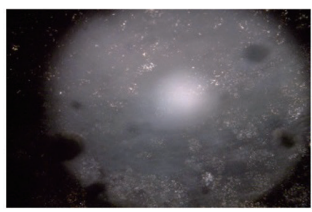

(16) $36.6 \mathrm{~h}, 900{ }^{\circ} \mathrm{C}$

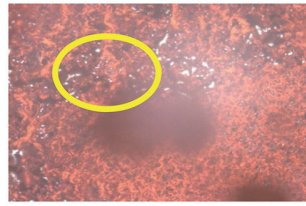

(21) $49 \mathrm{~h}, 900{ }^{\circ} \mathrm{C}$

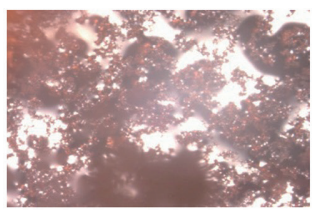

(26) $61 \mathrm{~h}, 900{ }^{\circ} \mathrm{C}$

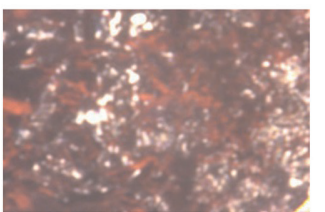

(31) $66 \mathrm{~h}, 900{ }^{\circ} \mathrm{C}$

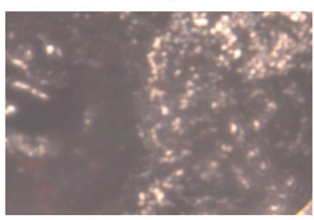

(36) $94 \mathrm{~h}, 25^{\circ} \mathrm{C}$

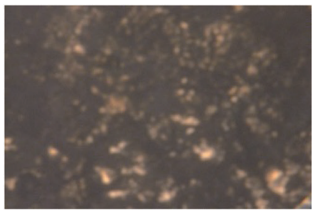

(3) $5 \mathrm{~h}, 900{ }^{\circ} \mathrm{C}$

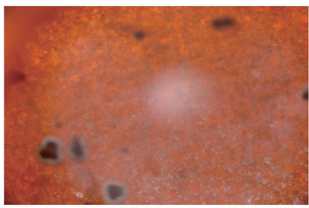

(8) $26 \mathrm{~h}, 25^{\circ} \mathrm{C}$

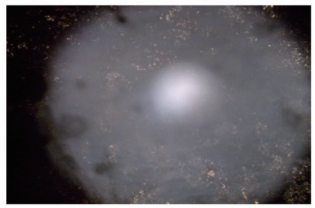

(13) $35.1 \mathrm{~h}, 900{ }^{\circ} \mathrm{C}$

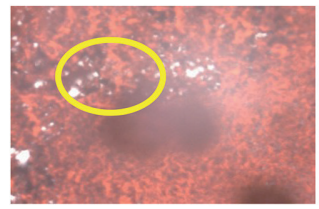

(18) $40 \mathrm{~h}, 25^{\circ} \mathrm{C}$

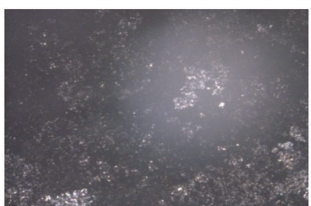

(23) $52 \mathrm{~h}, 900{ }^{\circ} \mathrm{C}$

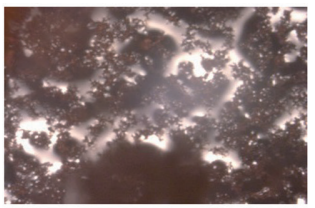

(28) $63 \mathrm{~h}, 900{ }^{\circ} \mathrm{C}$

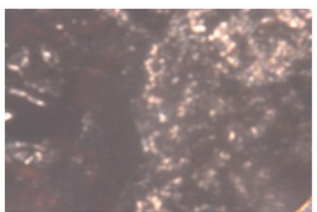

(33) $79 \mathrm{~h}, 900{ }^{\circ} \mathrm{C}$

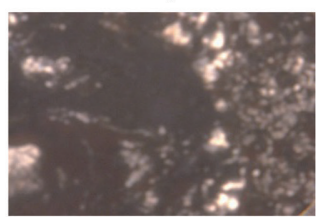

(34) $92 \mathrm{~h}, 900{ }^{\circ} \mathrm{C}$
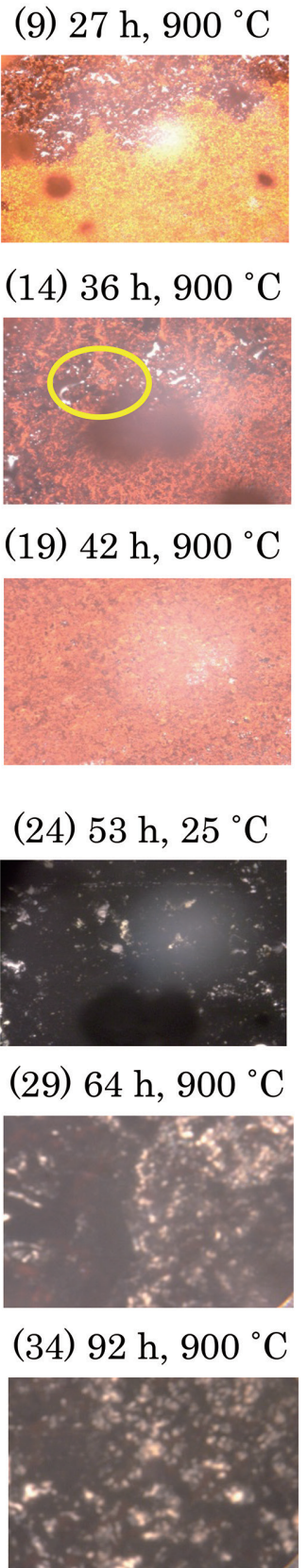

(14) $36 \mathrm{~h}, 900{ }^{\circ} \mathrm{C}$

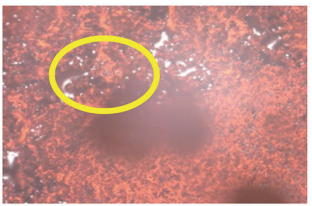

(19) $42 \mathrm{~h}, 900{ }^{\circ} \mathrm{C}$

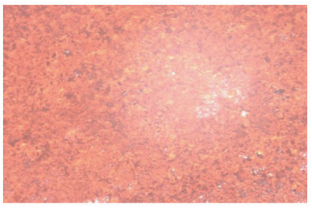

(24) $53 \mathrm{~h}, 25{ }^{\circ} \mathrm{C}$

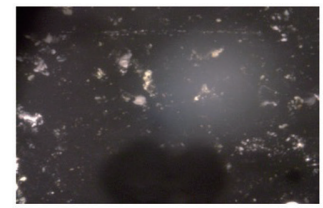

(29) $64 \mathrm{~h}, 900{ }^{\circ} \mathrm{C}$

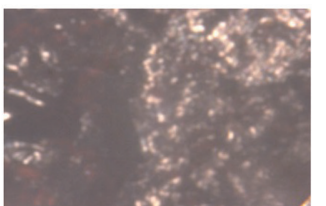

(32) $67 \mathrm{~h}, 25{ }^{\circ} \mathrm{C}$

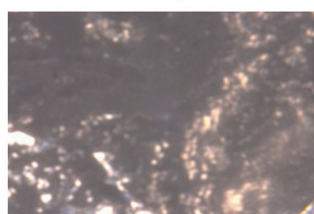

(37) $95.1 \mathrm{~h}, 900{ }^{\circ} \mathrm{C}$

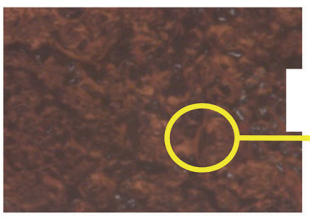

(5) $20 \mathrm{~h}, 25{ }^{\circ} \mathrm{C}$

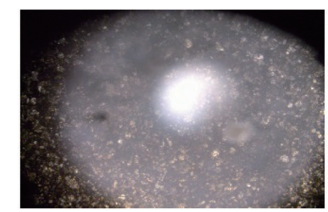

(10) $33 \mathrm{~h}, 900{ }^{\circ} \mathrm{C}$

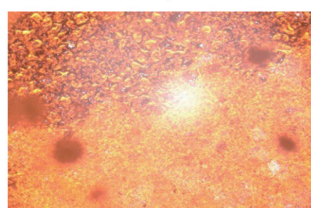

(15) $36.5 \mathrm{~h}, 900{ }^{\circ} \mathrm{C}$

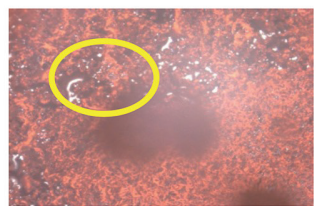

(20) $47 \mathrm{~h}, 25^{\circ} \mathrm{C}$

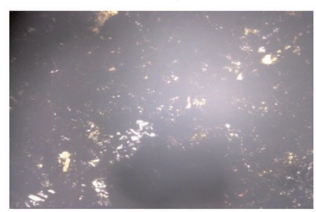

(25) $60 \mathrm{~h}, 25^{\circ} \mathrm{C}$

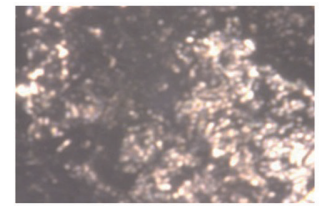

(30) $65 \mathrm{~h}, 900{ }^{\circ} \mathrm{C}$

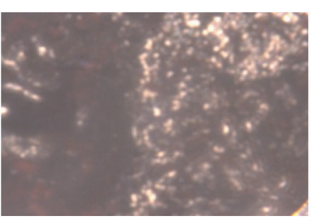

(35) $93 \mathrm{~h}, 900{ }^{\circ} \mathrm{C}$

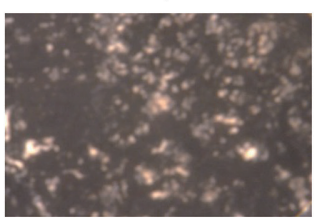

Fig. 15 Change in images, at magnifications of (1)-(11) 100, (12)-(24) 200, and (25)-(39) 1,000, of the surface of nickel plate with arsenic and selenium in heating-cooling stage with time and temperature 
(a) SEM image with more arsenic

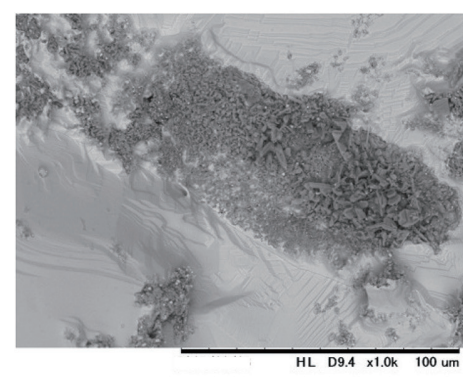

(b) SEM image with more selenium

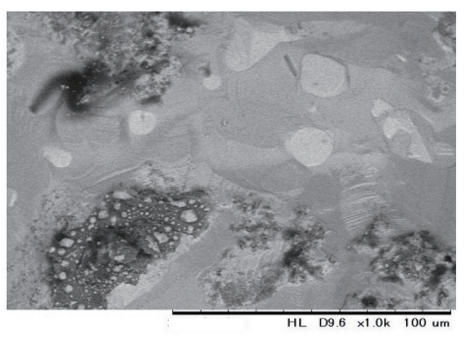

(c) SEM-EDX elemental mapping image with more arsenic

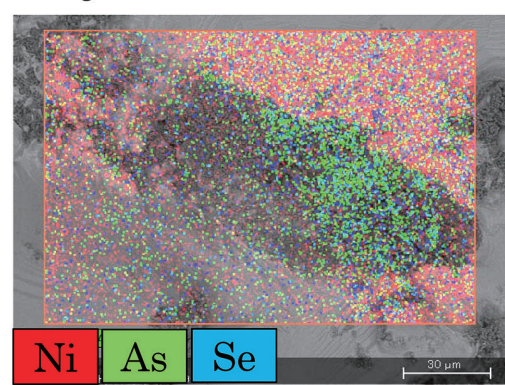

(d) SEM-EDX elemental mapping image with more selenium

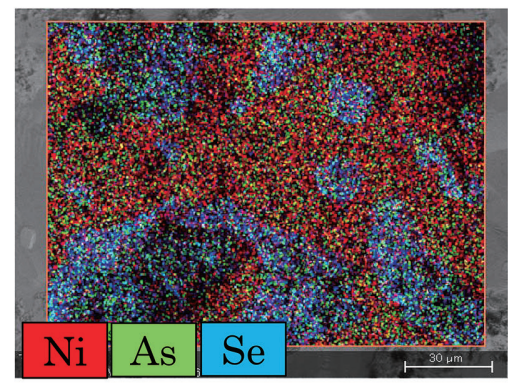

Fig. 16 (a), (b) SEM images and (c), (d) SEM-EDX elemental mapping images, at magnification of 1,000, of surface of nickel plates with more (a), (c) arsenic and (b), (d) selenium

5) Trembly, P. J.; Gemmen, S. R.; Bayless, J. D., J. Power Sources, 163, 986-996 (2007)

6) Martinez, A.; Gerdes, K.; Gemmen, R.; Poston, J., J. Power Sources, 195, 5206-5212 (2010)

7) Trembly, P. J.; Gemmen, S. R.; Bayless, J. D., J. Power Sources, 171, 818-825 (2007)

8) Krishnan, G., Proc. 8th Annual SECA Review Workshop, Aug.7-9, 2007, San Antonio, USA

9) Marina, A.O.; Pederson, R.L.; Edwards, J.D.; Coyle, W.C.; Templeton, J.; Engelhard, M.; Zhu, Z., Proc. 8th Annual SECA Review Workshop, Aug.7-9, 2007, San Antonio, USA

10) Coyle, A. C.; Marina, A. O.; Thomsen, C. E.; Edwards, J. D.; Cramer, D. C.; Coffey, W. G.; Pederson, R. L., J. Power Sources, 193, 730-738 (2009)

11) Gerdes, K.; Trembly, J.; Gemmen, R., Proc. Coal based
Fuel Cell Technology: Status, Needs and Future Applications, Oct.11-12, 2007, Morgantown, USA

12) Hackett, A. G.; Gerdes, K.; Song, X.; Chen, Y.; Shutthanandan, V.; Engelhard, M.; Zhu, Z.; Thevuthasan, S.; Gemmen, R., J. Power Sources, 214, 142-152 (2012)

13) Uchida, T., Kikuchi Y., Moritomi, H., Kumabe, K., Prep.1st Symposium on Applications of Advanced Measurement Technologies (SAAMT 2013), P06, Dec. 19-20, 2013, Tokushima, Japan : 内田智毅, 菊地悠介, 守 富寛，隈部和弘，第 1 回先端計測技術の応用展開に関する シンポジウム (SAAMT 2013) 前刷り，P06, 2013.12.1920 , 徳島

14) Okada, B., Watanabe, T., Mizuide, M., Outline of Electricity and Electronics, led, Corona Publishing Co., Ltd., 1984 : 岡田文平, 渡辺禎二, 水出正一, 電気・電子 工学概論, 初版, コロナ社, 1984 